Louisiana State University

LSU Digital Commons

Faculty Publications

Department of Biological Sciences

$12-1-2007$

\title{
Fluxes of iron and manganese across the sediment-water interface under various redox conditions
}

\author{
Svetlana V. Pakhomova \\ P.P.Shirshov Institute of Oceanology, Russian Academy of Sciences \\ Per O.J. Hall \\ Göteborgs Universitet \\ Mikhail Yu Kononets \\ Lomonosov Moscow State University \\ Alexander G. Rozanov \\ P.P.Shirshov Institute of Oceanology, Russian Academy of Sciences \\ Anders Tengberg \\ Göteborgs Universitet
}

See next page for additional authors

Follow this and additional works at: https://digitalcommons.Isu.edu/biosci_pubs

\section{Recommended Citation}

Pakhomova, S., Hall, P., Kononets, M., Rozanov, A., Tengberg, A., \& Vershinin, A. (2007). Fluxes of iron and manganese across the sediment-water interface under various redox conditions. Marine Chemistry, 107 (3), 319-331. https://doi.org/10.1016/j.marchem.2007.06.001

This Article is brought to you for free and open access by the Department of Biological Sciences at LSU Digital Commons. It has been accepted for inclusion in Faculty Publications by an authorized administrator of LSU Digital Commons. For more information, please contact ir@lsu.edu. 
Authors

Svetlana V. Pakhomova, Per O.J. Hall, Mikhail Yu Kononets, Alexander G. Rozanov, Anders Tengberg, and Andrei V. Vershinin 


\title{
Fluxes of iron and manganese across the sediment-water interface under various redox conditions
}

\author{
Svetlana V. Pakhomova ${ }^{\mathrm{a}, *}$, Per O.J. Hall ${ }^{\mathrm{b}}$, Mikhail Yu. Kononets ${ }^{\mathrm{c}}$, \\ Alexander G. Rozanov ${ }^{\mathrm{a}}$, Anders Tengberg ${ }^{\mathrm{b}}$, Andrei V. Vershinin ${ }^{\mathrm{a}}$ \\ ${ }^{a}$ P.P. Shirshov Institute of Oceanology, Russian Academy of Sciences, Nakhimovskii Prospekt 36, 117997 Moscow, Russia \\ b Department of Chemistry, Marine Chemistry, Göteborg University, SE-412 96 Göteborg, Sweden \\ ${ }^{c}$ Department of Basic Medicine, M.V. Lomonosov Moscow State University, Lomonosovsky Prospect 31 Bldg. 5, 119192 Moscow, Russia
}

Received 20 October 2006; received in revised form 30 May 2007; accepted 4 June 2007

Available online 9 June 2007

\begin{abstract}
Fluxes of dissolved forms of iron and manganese across the sediment-water interface were studied in situ in the Gulf of Finland and the Vistula Lagoon (Baltic Sea), and in the Golubaya Bay (Black Sea) from 2001 to 2005. Fluxes were measured using chamber incubations, and sediment cores were collected and sliced to assess the porewater and solid phase metal distribution at different depths. Measured and calculated benthic fluxes of manganese and iron were directed out of sediment for all sites and were found to vary between $70-4450$ and $5-1000 \mu$ mole $\mathrm{m}^{-2}$ day $^{-1}$ for manganese and iron, respectively. The behavior of the studied metals at various redox conditions in the near-bottom water and in the sediment was the main focus in this study. Our results show the importance of bottom water redox conditions for iron fluxes. We measured no fluxes at oxic conditions, intermediate fluxes at anoxic conditions (up to $200 \mu$ mole $\mathrm{m}^{-2}$ day $^{-1}$ ) and high fluxes at suboxic conditions (up to $1000 \mu$ mole $\mathrm{m}^{-2}$ day $^{-1}$ ). Total dissolved iron fluxes were generally dominated by iron(II). Contribution of iron(III) to the total iron flux did not exceed $20 \%$. Obtained fluxes of manganese at all studied regions showed a linear correlation $\left(r^{2}=0.97\right)$ to its concentration in the porewater of the top sediment layer $(0-5 \mathrm{~mm})$ and did not depend on dissolved oxygen concentrations of bottom water. Organically complexed iron and manganese were in most cases not involved in the benthic exchange processes.
\end{abstract}

(c) 2007 Elsevier B.V. All rights reserved.

Keywords: Iron; Manganese; Dissolved metal fluxes; Speciation; Valent forms; Organic forms; Oxic/anoxic interface; Sediment-water interface

\section{Introduction}

It is well known that concentrations of dissolved forms of iron and manganese undergo drastic changes with depth in water columns with diminished oxygen concentration such as in the oxygen minimum zones of

\footnotetext{
* Corresponding author.

E-mail address: s-pakhomova@yandex.ru (S.V. Pakhomova).
}

the Pacific and Indian (Arabian Sea) oceans, and in anoxic basins with oxygenated surface water such as Framvaren Fjord (Landing and Westerlund, 1988), the Cariaco Trench (Bacon et al., 1980; Zhang and Millero, 1993), the Baltic Sea (Kremling, 1983), and the Black Sea (Spencer and Brewer, 1971, 1972; Lewis and Landing, 1991; Pakhomova, 2005).

These studies have demonstrated that two main processes describe the redox cycles of iron and manganese in any basin with a transition from oxic to 
anoxic conditions. Reduced forms of the metals are dissolved in suboxic or anoxic seawater. Oxidation of dissolved forms, supplied from below, occurs in the upper part of the water column under action of oxygen or other oxidants. As a result, oxidized particulate forms of the metals are produced. Particulate metals sink downwards due to gravity and are then reduced in the suboxic or anoxic zone. Reductive dissolution of hydrated oxides of iron(III) and manganese(III, IV) controls the supply of dissolved reduced forms of the metals in the anoxic zone. The redox cycles of the metals are vertically structured with the upper part of water column where oxidation dominates separated from the deeper part where reduction of iron(III) and manganese(III,IV) oxides is the main process. This vertical structure is mainly controlled by the availability of oxygen.

Strong vertical gradients of dissolved iron and manganese also exist in porewaters of most coastal and continental margin sediments. Also here, the transformation of
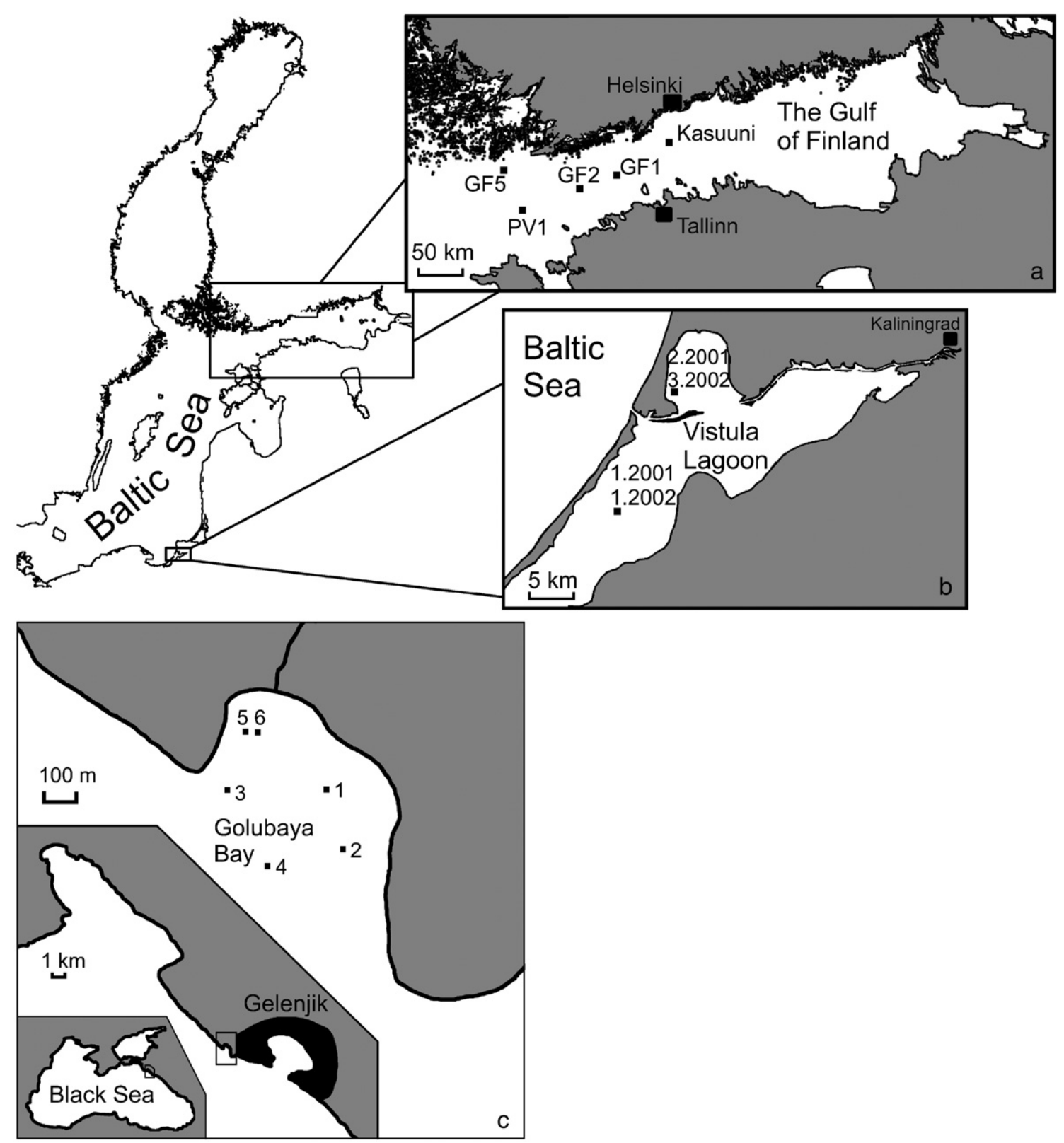

Fig. 1. Sampling locations in the Gulf of Finland (a), the Vistula Lagoon (b) and in the Golubaya Bay (c). 
oxidized to reduced forms (and vice versa) is directly or indirectly controlled by the supply of oxygen, which is strongly coupled to the oxidation of organic matter in sediments.

Benthic flux-chamber experiments performed in situ have shown substantial and increasing fluxes of iron and manganese from the sediment during the phase of the experiment when the oxygen content of the enclosed water was decreasing from the initial, ambient value towards zero (e.g., Hallberg et al., 1972; Lindstrom, 1980; Balzer, 1982; Sundby et al., 1986; Skoog et al., 1996). However, when oxygen was maintained at the ambient level in the water of the chambers throughout experiments, there was no release of iron and manganese from the sediment. On the contrary, the metals were taken up by the sediment from the overlying water during such conditions (Sundby et al., 1986; Skoog et al., 1996).

The aim of this study was to further examine the in situ rate and extent of release of dissolved iron and manganese from different types of sediments in the Gulf of Finland and in the Vistula Lagoon (Baltic Sea), and in the Golubaya Bay (Black Sea) under various redox conditions. We also determined the speciation of the metals released from the sediment, and to what extent the benthic fluxes could be predicted from porewater gradients and contents of oxidized forms of these metals in the sediment.

\section{Study sites}

Benthic fluxes of iron and manganese were studied in three different regions employing two different in situ techniques as well as traditional sediment sampling and porewater extraction techniques.

The Gulf of Finland (GoF) is the most eutrophicated (over-fertilized) sub-basin of the Baltic Sea and oxygen conditions are highly variable at many locations, depending on the water circulation and the time of the year. In this area five locations (Fig. 1a) were visited during four expeditions. Three of these locations, called GF1, GF2 and GF5, were only studied in June 2002. The other two (Kasuuni and PV1) were repeatedly occupied during three expeditions in June-July 2003, September 2004 and May 2005. Information about time of sampling, water depth, sediment characteristics, bottom water oxygen, and sedimentary metal concentrations is given in Table 1.

The Vistula Lagoon (Baltic Sea) is a site with very shallow depth (1-4 m), and it has a very limited water exchange with the open sea (Fig. 1b). It receives high river and anthropogenic loads resulting in high biological activity. The Lagoon is nevertheless a well- oxygenated basin with high concentrations of suspended particulate organic matter. Studies were carried out in August 2001 and 2002. Additional data are presented in Table 1.

The Golubaya Bay (Black Sea) is a well-oxygenated open bay with a small inflow of Ashamba River which dries up completely in summer (Fig. 1c). Its main feature is the presence of anoxic sediments, occupying about $10 \%$ of the bottom area, with a high content of organic matter. The Golubaya Bay has a maximum depth of $20 \mathrm{~m}$. Studies were carried out in September 2000-2002. Additional data are presented in Table 1.

\section{Materials and methods}

\subsection{Flux measurements}

To investigate the exchange processes of iron and manganese between the water and the sediment in the GoF we used an autonomous chamber incubation lander (described in detail in, e.g., Tengberg et al., 2003; Ståhl et al., 2004). This lander is equipped with four squared $(20 \times 20 \mathrm{~cm})$ incubation chambers which after careful insertion into the sediment isolate the sediment together with a ca. $25-\mathrm{cm}$-high column of ambient bottom water. A more precise estimate of the incubated water volume is obtained by injection of bromide according to the method described in Jahnke and Christiansen (1989). A controlled mixing inside the chamber is assured by a horizontally placed paddle wheel which runs across the chamber (Tengberg et al., 2004). During incubations, which in the GoF lasted for 15-60 h, nine 60-mL samples were automatically withdrawn from the incubated water in each chamber using polypropylene syringes. After recovery of the lander the water samples were filtered and analyzed to obtain the concentration changes with time, which were used together with chamber water column height to calculate benthic fluxes of iron and manganese. The dissolved oxygen concentrations inside the chambers and in the ambient bottom water were monitored at 1-min intervals with accurate and stable oxygen optodes (Tengberg et al., 2006). Also suspended particle concentrations in the chambers were monitored with turbidity sensors which signaled the existence of any unwanted resuspension event (e.g., during chamber penetration or by trapped fauna) in the chambers.

Before each expedition the entire chambers and sampling systems (syringes and tubes) were carefully cleaned with detergent, soaked in $1 \mathrm{M} \mathrm{HCl}$ for at least $24 \mathrm{~h}$, and then rinsed and soaked in distilled water. 
Table 1

Concentration of oxygen and dissolved metals in the near-bottom water (bw) and characteristics of sediments (sed) at the studied stations

\begin{tabular}{|c|c|c|c|c|c|c|c|c|}
\hline Station & $\begin{array}{l}\text { Date of } \\
\text { sampling }\end{array}$ & $\begin{array}{l}\text { Station } \\
\text { depth } \\
{[\mathrm{m}]}\end{array}$ & $\begin{array}{l}c\left(\mathrm{O}_{2}\right)_{\mathrm{bw}} \\
{[\mu \mathrm{M}]}\end{array}$ & $\begin{array}{l}c(\mathrm{Mn})_{\mathrm{bw}} / \\
c(\mathrm{Fe})_{\mathrm{bw}} \\
{[\mu \mathrm{M}]}\end{array}$ & $\begin{array}{l}\text { Redox } \\
\text { conditions } \\
\text { at interface } \\
\text { bw/sed }\end{array}$ & $\begin{array}{l}c(\mathrm{Mn})_{\mathrm{sed}} \\
{[\%]}\end{array}$ & $\begin{array}{l}c(\mathrm{Fe})_{\mathrm{sed}} \\
{[\%]}\end{array}$ & Sediment description \\
\hline
\end{tabular}

\begin{tabular}{llrlllll}
\hline \multicolumn{2}{l}{ Golubaya Bay (Black Sea) } & & & & & \\
1 & 09.2000 & 10 & 240 & $0.5 / 0$ & Oxic/Oxic & - & - \\
2 & 09.2001 & 12 & 190 & $0.13 / 0.03$ & Oxic/Anoxic & 0.015 & 0.9 \\
3 & 09.2001 & 7 & 210 & $0.05 / 0.04$ & Oxic/Anoxic & & \\
4 & 09.2001 & 15 & 210 & $0.05 / 0$ & Oxic/Anoxic & & \\
5 & 09.2002 & 10 & 230 & $0.4 / 0.05$ & Oxic/Oxic & $0.03-0.08$ & $1.4-1.6$ \\
6 & 09.2002 & 10 & 230 & $0.35 / 0.02$ & Oxic/Oxic & $0.03-0.085$ & $1.2-1.8$
\end{tabular}

Aleuritic mud with sand

Pelitic mud; black semi-fluid with a smell of hydrogen sulfide, $10 \%$ of bay sediment Aleuritic mud; oxidized upper layer (st. 5, 0-2 cm; st. 6 $0-8 \mathrm{~cm}$ ), from Ashamba river

Vistula Lagoon (Baltic Sea)

$\begin{array}{llllclll}1.2001 & 08.2001 & 2 & 220 & 0.2 / 0.24 & \text { Oxic/Oxic } & 0.015-0.018 & 1.6-1.7 \\ 2.2001 & 08.2001 & 2 & 260 & 1.26 / 0.42 & \text { Oxic/Oxic } & 0.01-0.012 & 1.1-1.3 \\ 1.2002 & 08.2002 & 2 & 280 & 0.6 / 0.12 & \text { Oxic/Oxic } & 0.014-0.017 & 1.3-1.5 \\ 3.2002 & 08.2002 & 4 & 290 & 1.12 / 0.2 & \text { Oxic/Oxic } & 0.012-0.017 & 1.1-1.4\end{array}$

The Gulf of Finland (Baltic Sea)

\begin{tabular}{|c|c|c|c|c|c|c|c|c|}
\hline GF1 & 06.2002 & 79 & 0 & $6.8 / 1.95$ & Anoxic/Anoxic & $0.019-0.024$ & $3.7-4.0$ & \multirow{2}{*}{$\begin{array}{l}\text { Pelitic mud; black, semi-fluid with a } \\
\text { smell of hydrogen sulfide }\end{array}$} \\
\hline GF2 & 06.2002 & 86 & 0 & $7.1 / 1.98$ & Anoxic/Anoxic & $0.022-0.026$ & $3.9-4.3$ & \\
\hline GF5 & 06.2002 & 53 & 340 & $0.64 / 0.03$ & Oxic/Oxic & $0.012-0.04$ & $1.2-1.6$ & $\begin{array}{l}\text { Aleuritic mud (with sand in horizons } \\
1-3 \mathrm{~cm} \text { ) }\end{array}$ \\
\hline PV1(03) & 06.2003 & 76 & 0 & $2.5 / 0.16$ & Anoxic/Anoxic & $0.03-0.035$ & $3.5-4.2$ & \multirow{3}{*}{$\begin{array}{l}\text { Pelitic mud; black, semi-fluid with } \\
\text { a smell of hydrogen sulfide }\end{array}$} \\
\hline PV1(04) & 09.2004 & 80 & 120 & $0.58 / 0.03$ & Oxic/Anoxic & $0.025-0.03$ & $3-3.2$ & \\
\hline PV1(05) & 05.2005 & 79 & 10 & $2.6 / 0.1$ & Suboxic/Anoxic & $0.031-0.036$ & $3.1-3.7$ & \\
\hline $\operatorname{Kas}(03)$ & 06.2003 & 43 & 150 & $0.75 / 0.03$ & Oxic/Oxic & $0.1-0.16$ & $3.5-3.7$ & \multirow{3}{*}{$\begin{array}{l}\text { Aleuritic-pelitic mud with } \\
\text { ferromanganese nodules }\end{array}$} \\
\hline $\operatorname{Kas}(04)$ & 09.2004 & 55 & 220 & $0.56 / 0.03$ & Oxic/Oxic & $0.3-1.7$ & $4-6.5$ & \\
\hline $\mathrm{Kas}(05)$ & 05.2005 & 55 & 200 & $0.95 / 0.03$ & Oxic/Oxic & $0.5-1.4$ & $3.9-6.2$ & \\
\hline
\end{tabular}

In parallel with the lander experiments virtually undisturbed sediment cores, $10 \mathrm{~cm}$ in diameter, were collected together with overlying water using a multiple corer (Barnett et al., 1984). Upon recovery these cores were sliced at in situ temperature in 0.5 - to 1.0 -cm-thick slices. The sediment was placed into centrifuge tubes, and the porewater was extracted by centrifugation (3000 RPM for $30 \mathrm{~min}$ ). The extracted porewater was filtered and analyzed to obtain porewater profiles of the studied metals. Also the solid phase of the sediment was analyzed for iron and manganese content.

In the Golubaya Bay and the Vistula Lagoon three cylindrical (total height, $30 \mathrm{~cm}$; incubated water height, $25 \mathrm{~cm}$; and diameter, $25 \mathrm{~cm}$ ) diver-operated chambers were deployed simultaneously at every occasion. Water in the chambers was mixed by the ambient currents which were driving a rotor with cups, placed on top of each chamber. This rotor is magnetically coupled to a centrally placed stirrer (Vershinin and Rozanov, 1999, 2002). Water samples (200-300 mL) from the chambers and from the ambient water were collected in syringes by divers several times per day.
Two of the chambers were inserted into the sediment and served for flux incubations. A third "blank chamber" had a rubber membrane, which isolated it from the sediment. It only incubated bottom water and consequently served to obtain information and compensate for mineralization processes in the water phase.

In addition, sediment samples were collected by the divers using traditional coring techniques. Like in the $\mathrm{GoF}$, these cores were sliced and both porewater and solid phase samples were extracted and analyzed for iron and manganese.

\subsection{Analytical methods}

All water samples were filtered through pre-rinsed (with Milli-Q water) cellulose acetate membrane filters with a pore size of $0.45 \mu \mathrm{m}$ prior to analysis, which was carried out as rapidly as possible (within $1 \mathrm{~h}$ after sampling). Dissolved forms of iron and manganese were determined photometrically using ferrozine and formaldoxyme procedures, respectively (Peshkova and Ovsyannikova, 1937; Grashoff et al., 1999; Kononets et al., 2002; Pakhomova, 
2005). The investigated dissolved metal forms were $\mathrm{Mn}$ (II), $\mathrm{Fe}(\mathrm{II}), \mathrm{Fe}(\mathrm{III}), \mathrm{Mn}_{\text {org }}$ and $\mathrm{Fe}_{\text {org. }}$. Dissolved $\mathrm{Fe}$ (III) concentration was calculated as the difference between the concentration of total dissolved iron $\left(\mathrm{Fe}_{\Sigma}\right.$, obtained after reduction of iron(III) by ascorbic acid) and the concentration of iron(II). Measured iron(III) could include colloidal forms which passed through the filter and would then be measured as dissolved iron (Kononets et al., 2002; Pakhomova, 2005). Dissolved marine organic matter was decomposed using UV irradiation with an addition of hydrogen peroxide $\left(50 \mu \mathrm{L}\right.$ of $30 \% \mathrm{H}_{2} \mathrm{O}_{2}$ per $20 \mathrm{~mL}$ of sample) at $\mathrm{pH} 2$ during $1 \mathrm{~h}$. An 80-W high-pressure $\mathrm{Hg}$ lamp was used as a source of UV radiation. Then total dissolvable iron and manganese concentrations were determined photometrically. We called the difference between total dissolvable and dissolved metals iron and manganese complexed with marine organic matter $\left(\mathrm{Mn}_{\text {org }}\right.$ and $\left.\mathrm{Fe}_{\text {org }}\right)$. Precision of dissolved metal analysis was typically $3 \%$. Detection limits were 20 and $100 \mathrm{nM}$ for iron and manganese, respectively.

Iron and manganese content in the solid phase of the sediment was analyzed using a wet acidic dissolution technique with $\mathrm{HClO}_{4}$ and $\mathrm{HF}$ acids (Ponomarev, 1961) followed by atomic-absorption spectroscopic determination of the metals on a graphite furnace spectrometer Perkin Elmer 603.

\subsection{Flux calculations}

Linear approximation with compensation for the withdrawn chamber water was used to calculate fluxes of dissolved species in the chamber experiments $\left(J_{\mathrm{ch}}\right)$. This method is described in detail in Ståhl et al. (2004). Fick's first law was used according to Berner (1980) to calculate diffusive fluxes from the porewater gradients $\left(J_{\mathrm{pw}}\right)$. Molecular diffusion coefficients were obtained from Li and Gregory (1974) with temperature correction and were equal to 3.25 and $5.89 \times 10^{-6} \mathrm{~cm}^{2} \mathrm{~s}^{-1}$ for a mean temperature in the bottom water of $5^{\circ} \mathrm{C}(\mathrm{GoF})$ and $25^{\circ} \mathrm{C}$ (Vistula Lagoon, Golubaya Bay).

\section{Results}

The selection of study sites provided the following combination of redox conditions at bottom water/ sediment interface: oxic/oxic, anoxic/anoxic, oxic/anoxic, suboxic/anoxic and oxic/oxic with high bioactivity (Table 1). All the stations in the Golubaya Bay and the Vistula Lagoon were shallow and bottom waters were well oxygenated. Concentrations of dissolved oxygen in the bottom water were 190-290 $\mu \mathrm{M}$ (Table 1). In the GoF the stations were located deeper and the oxygen conditions were variable depending on the location of the station and when it was visited. Combined long-term (8-10 months) measurements and modeling indicate that bottom water oxygen conditions in large parts of the GoF shift from anoxic to oxic and back on time scales of hours to days (Tengberg et al., personal communication). This was the case also in this study and for example station PV1 was anoxic in 2003, oxic in 2004 and suboxic (oxygen concentrations around $10 \mu \mathrm{M}$ ) in 2005. Stations GF1, GF2 were anoxic, and the shallower stations GF5 and Kasuuni were oxic with variable oxygen concentrations from 120 to $340 \mu \mathrm{M}$ (Table 1).

The content of manganese in the solid phase of sediment was $0.01-0.08 \%$ of sediment dry weight with the exception of station Kasuuni, where ferromanganese nodules were found, and manganese reached $1.7 \%$ of sediment dry weight. The content of iron was between 1.1 and $1.8 \%$ for sediments of the Golubaya Bay and the
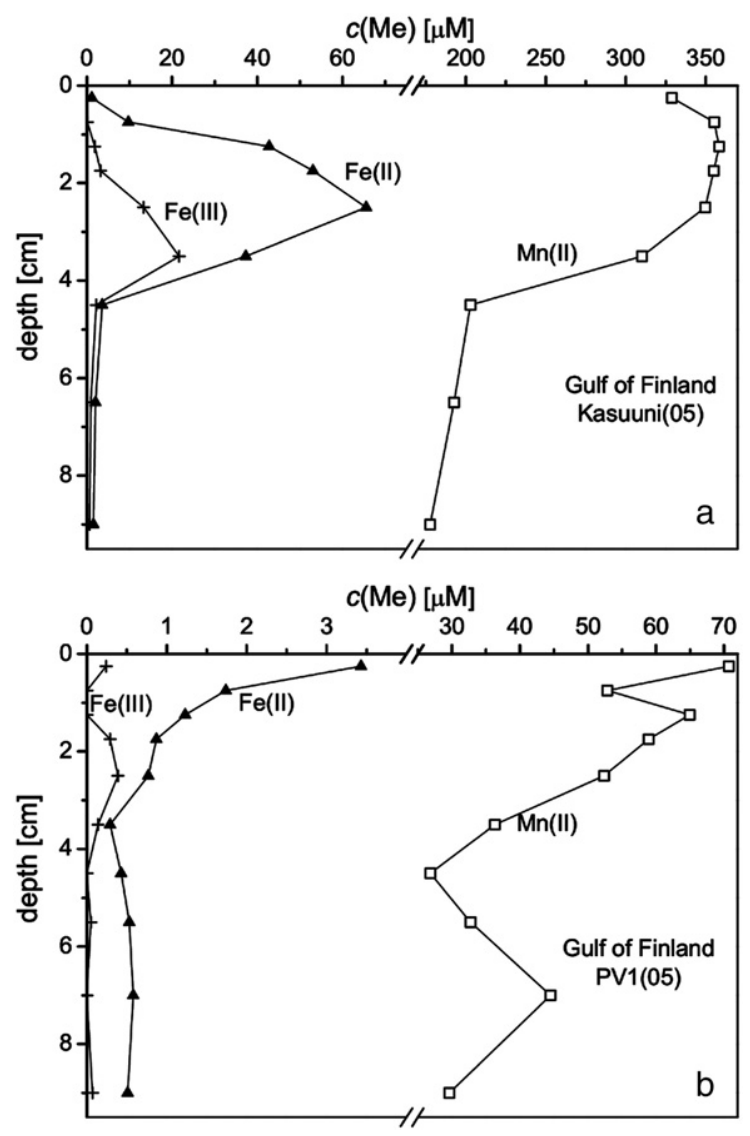

Fig. 2. Distribution of dissolved manganese, iron(II) and iron(III) in porewater on the stations Kasuuni (a) and PV1(b), the Gulf of Finland. The concentration of oxygen in the near-bottom water was 240 and $10 \mu \mathrm{M}$, respectively. 
Vistula Lagoon. In the GoF sediments the iron fractions were generally at least twice as high reaching as much as $6.5 \%$ on station Kasuuni (Table 1).
At the majority of stations the porewater concentration of dissolved manganese of the top sediment layers varied from 20 to $60 \mu \mathrm{M}$ (Fig. 2b). Exceptions were
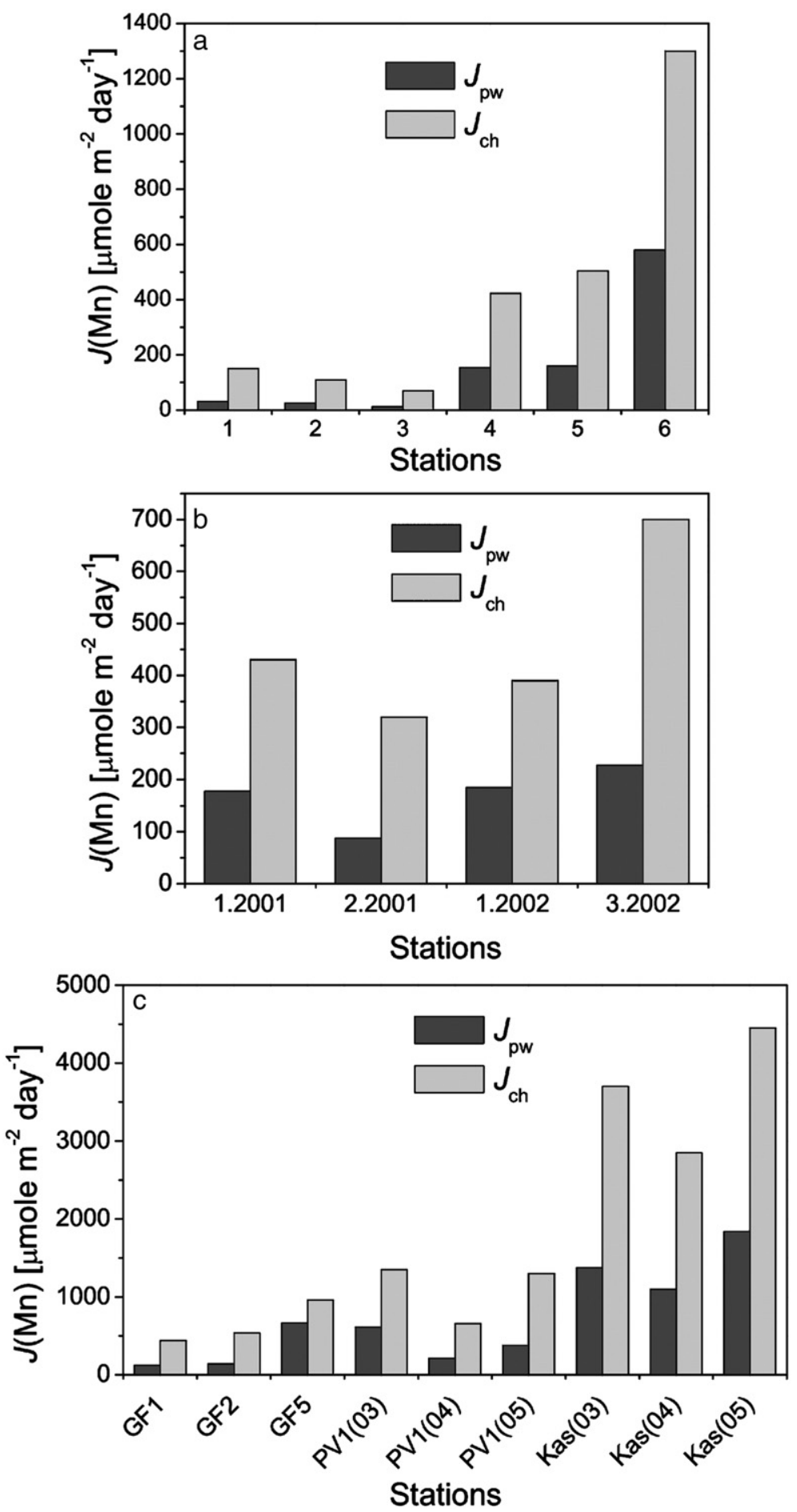

Fig. 3. Fluxes of dissolved manganese out of sediment obtained by in situ chamber incubations $\left(J_{\mathrm{ch}}\right)$ and from porewater gradient calculations $\left(J_{\mathrm{pw}}\right)$ for the Golubaya Bay (a), the Vistula Lagoon (b), and the Gulf of Finland (c). 
again station Kasuuni in the GoF (Fig. 2a) and station 6 in the Golubaya Bay, which is located near the outflow of the Ashamba river. Here dissolved porewater manganese reached up to $300 \mu \mathrm{M}$ and $120 \mu \mathrm{M}$, respectively.

Porewater concentrations of dissolved iron varied rather much between different stations and were mainly coupled to the prevailing ambient bottom water oxygen levels. For the majority of stations the porewater iron concentrations in the uppermost sediment layer $(0-$ $1 \mathrm{~cm}$ ) were $2-6 \mu \mathrm{M}$. Then a maximum of up to $120 \mu \mathrm{M}$ of iron was observed in the porewater of oxic sediments in the next sediment layer (Fig. 2a). On the contrary, for the anoxic sediments concentration of iron in the porewater of the same sediment layer decreased and did not exceed $20 \mathrm{nM}$ (Fig. 2b). In case of anoxic
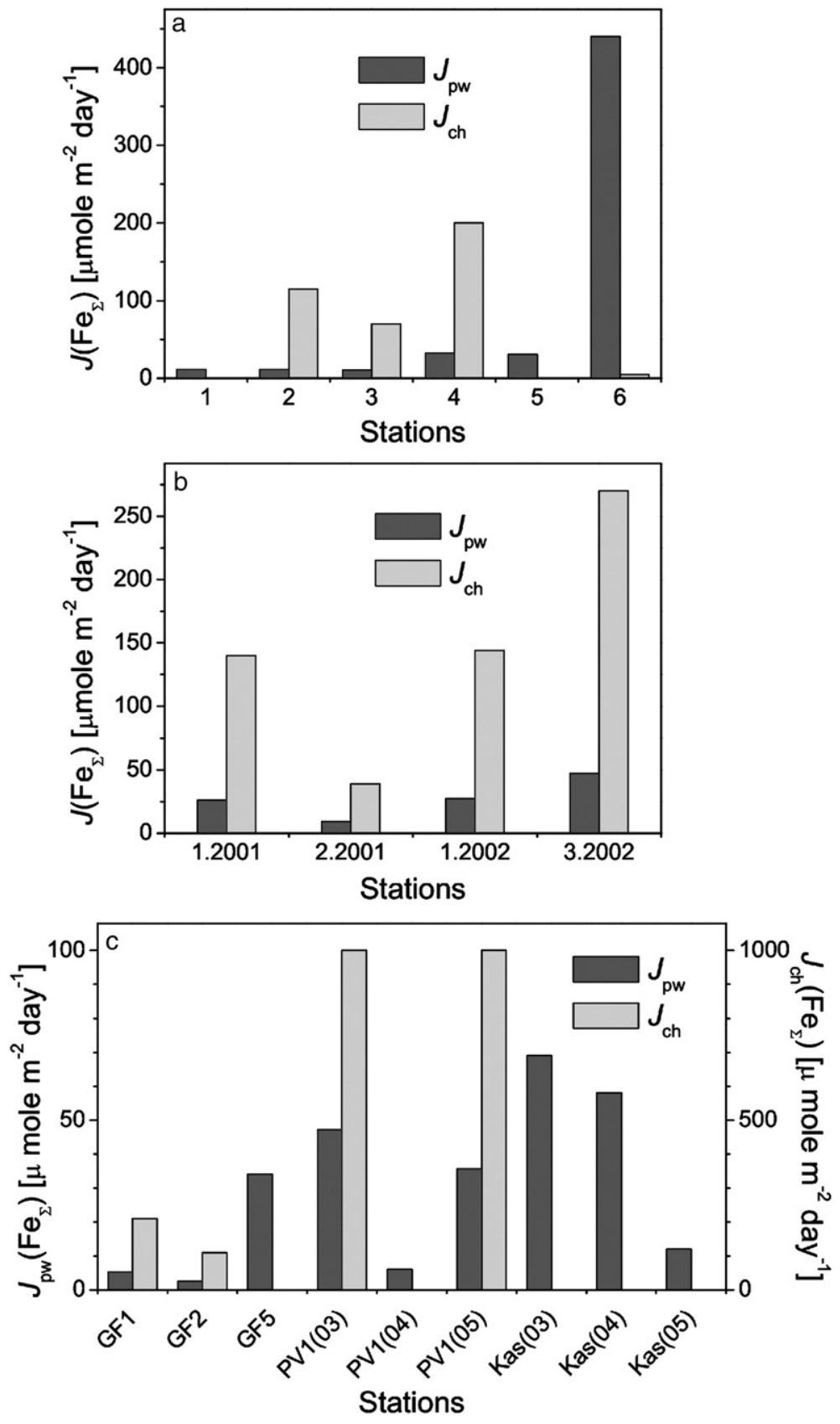

Fig. 4. Fluxes of dissolved iron out of sediment obtained by in situ chamber incubations $\left(J_{\mathrm{ch}}\right)$ and from porewater gradient calculations $\left(J_{\mathrm{pw}}\right)$ for the Golubaya Bay (a), the Vistula Lagoon (b), and the Gulf of Finland (c). 
Table 2

In situ measured $\left(J_{\mathrm{ch}}\right)$ and diffusive $\left(J_{\mathrm{pw}}\right)$ benthic fluxes of iron and manganese in this and some previous studies [ $\mu$ mole $\mathrm{m}^{-2}$ day ${ }^{-1}$ ]

\begin{tabular}{|c|c|c|c|c|}
\hline & \multicolumn{2}{|l|}{$\mathrm{Mn}$} & \multicolumn{2}{|l|}{$\mathrm{Fe}$} \\
\hline & $J_{\mathrm{pw}}$ & $J_{\mathrm{ch}}$ & $J_{\mathrm{pw}}$ & $J_{\mathrm{ch}}$ \\
\hline This study & $13-2000$ & $70-4450$ & $3-400$ & $5-1000$ \\
\hline Aller (1994) & $-10-4590$ & $-70-3800$ & - & - \\
\hline Berelson et al. (2003) & - & $3-18$ & - & $1.3-11$ \\
\hline Friedl et al. (1998) & - & $40-2300$ & - & $0-2100$ \\
\hline Skoog et al. (1996) & - & - & - & $19-400$ \\
\hline Sundby et al. (1986) & 93 & 66 & 20 & 300 \\
\hline Thamdrup et al. (1994) & $410-1200$ & $26-600$ & - & - \\
\hline Warnken et al. (2001) & $20-370$ & $420-2600$ & $7-94$ & $4-39$ \\
\hline
\end{tabular}

Negative fluxes mean fluxes directed into the sediment, and positive out of the sediment.

sediments practically all dissolved porewater iron occurred as iron(II) (station PV1 in the Gulf of Finland, Fig. 2b, and stations 3 and 4 in the Golubaya Bay). In case of oxic sediments iron(III) constituted $20-30 \%$ of total dissolved porewater iron (Fig. 2a), but occasionally reached up to $50-60 \%$ at some stations, e.g., station 6 in the Golubaya Bay.

Measured and calculated benthic fluxes of manganese (Fig. 3) and iron (Fig. 4) were directed out of sediment for all sites and were found to vary between 70-4450 and 5$1000 \mu$ mole $\mathrm{m}^{-2}$ day $^{-1}$ for manganese and iron, respectively. These values are in a range of previously reported flux measurements (Table 2) for shallow coastal regions, mostly oxic, by Sundby et al. (1986), Aller (1994), Thamdrup et al. (1994), Skoog et al. (1996), Friedl et al. (1998), Warnken et al. (2001), and Berelson et al. (2003).

\section{Discussion}

\subsection{Manganese}

Manganese fluxes at all the sites were found to be independent of prevailing bottom water oxygen conditions (Fig. 5a) as well as of organic carbon oxidation rates (Andersson et al., personal communication), which were obtained from in situ measurements of benthic oxygen and dissolved inorganic carbon fluxes, respectively. Similar values of manganese fluxes were obtained for many stations in the Gulf of Finland although the redox conditions in the near-bottom water at these stations were different. For example, both manganese fluxes and manganese porewater concentrations at the station GF2 were similar to those at PV1(04) (Fig. 3c) in spite of the fact that GF2 had anoxic bottom water and PV1(04) - oxic. The highest fluxes of manganese and the highest concentrations of manganese in porewater in 2003, 2004 and 2005 were measured at the station Kasuuni (Fig. 3c). Similar values of manganese fluxes were also obtained in the Golubaya Bay for stations with different oxygen fluxes. At stations 1, 2 and 4, 5 in the Golubaya Bay oxygen had equal initial bottom water concentrations and different (up to factor of 4) oxygen fluxes, but manganese fluxes were similar (Fig. 3a) and porewater manganese concentrations were also similar at these stations. All this suggests that the flux of manganese did not depend neither on bottom water oxygen concentration nor on oxygen flux at the study sites.

Regardless of the region, the flux of manganese strongly correlated with the manganese concentration in the porewater of the top sediment layer. The flux of manganese is generally controlled by the concentration difference between porewater and bottom water (the gradient), but in our case bottom water concentrations of manganese were insignificant compared to porewater concentrations.

A good linear correlation between chamber manganese flux and porewater manganese concentration in the top sediment layer $(0-1 \mathrm{~cm})$ was observed for all studied regions (Fig. 6). The good agreement indicates
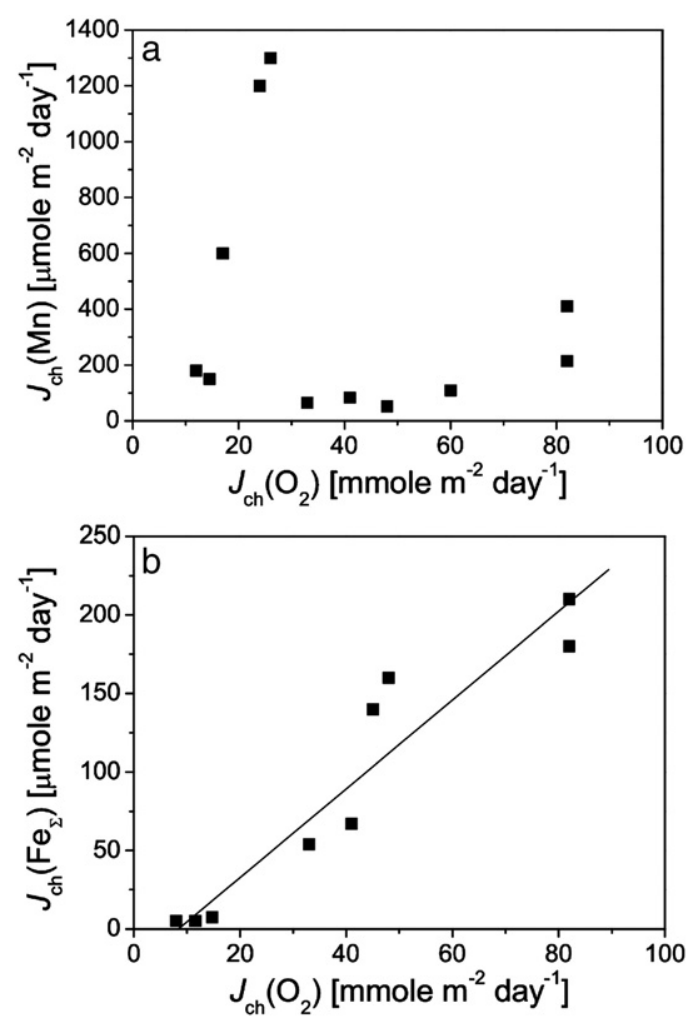

Fig. 5. Correlation between dissolved manganese (a) and iron (b) flux and flux of oxygen in the Golubaya Bay (Black Sea). For iron $r^{2}=0.95$ $(n=10, P=0.05)$. 


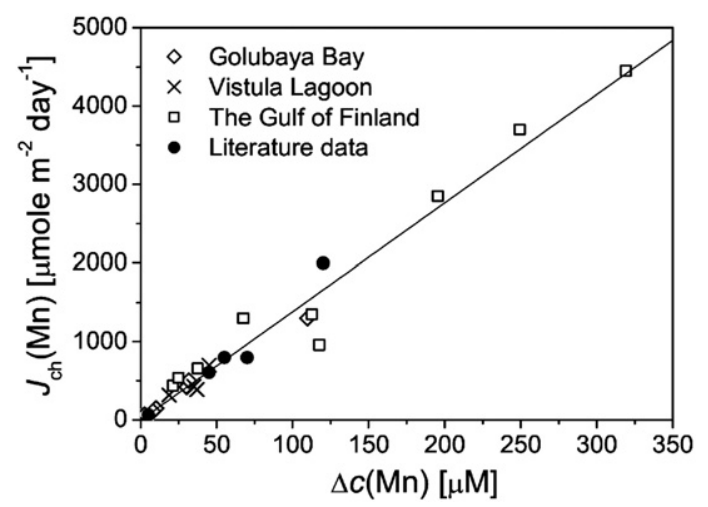

Fig. 6. Correlation of dissolved manganese flux to concentration gradient of manganese in porewater of the top sediment layer $(0-1 \mathrm{~cm})$ and in bottom water. Correlation equation: $J(\mathrm{Mn})\left[\mu \mathrm{mole}^{-2}\right.$ day $\left.^{-1}\right]=$ $(13.8 \pm 0.6) \times \Delta c(\mathrm{Mn})[\mu \mathrm{M}], r^{2}=0.97(n=19, P=0.05)$.

that the equation of this line may be used to estimate the magnitude of manganese fluxes from other sediments using the porewater concentration in the surface sediment. Previously reported data (Sundby et al., 1986; Fones et al., 2001; Warnken et al., 2001) also agree well with the observed correlation reported here (Fig. 6).

Aller (1994) described seasonal variability of manganese fluxes. The highest fluxes observed in summer decreased down to nearly zero in winter. Bottom water became suboxic during autumn, and manganese released into the water column and gradually decreased in the porewater of the top sediment layer. In winter manganese concentration in the porewater became the same as or even lower than in bottom water, and the flux was close to zero or directed into the sediment. Then bottom water became oxic again and dissolved manganese was oxidized and precipitated. In spring precipitated manganese in sediment started to dissolve resulting in a flux of dissolved manganese from porewater into bottom water. Thus, on a large timescale, the flux of manganese depends on redox conditions in bottom water which lead to a change of dissolved manganese content of the porewater. However, on a time scale of a single chamber incubation, the manganese flux does not depend on the concentration of oxygen (redox conditions), because for manganese the rate of oxidation is much lower than the rate of release from the sediment. The manganese flux is controlled by the porewater manganese concentration of the top sediment layer and released manganese can remain unchanged under oxic open-sea conditions for up to 8 days (Tebo, 1991). In shallow coastal regions oxidation of manganese may be strongly promoted by bacteria (Tebo, 1991). In that case the rate of manganese oxidation becomes comparable to or even exceeds the rate of dissolved manganese release from the sediment. This behavior of manganese was observed both previously (Thamdrup et al., 1994) and in the present work in the Vistula Lagoon.

The Vistula Lagoon was particular in that the decrease of manganese concentration in the chamber water followed its initial release during incubations. Thus, manganese fluxes eventually changed direction to be from bottom water into the sediment in spite of the fact that oxygen concentration decreased linearly. This effect was more distinctly observed at the stations in the middle of the Lagoon where the biological activity in the water was highest, detected through intense consumption of oxygen measured in "the blank chamber" at stations 1.2001 and 1.2002 (Yudin et al., 2005). We speculate that the change of direction of the manganese flux was a result of fast oxidation in the water of the metal released from the sediment, and the oxidation may have been promoted by bacteria. The worst correlation between manganese flux and its concentration in porewater for the Vistula Lagoon $\left(r^{2}=0.68\right)$ in comparison with the other studied regions $\left(r^{2}=0.96\right.$ and 0.99 for the GoF and the Golubaya Bay respectively) may indicate that manganese fluxes on stations 1.2001 and 1.2002 were slightly underestimated. The same can be stated for station GF5 in the GoF. However, the good correlation between fluxes and porewater concentrations for all sites suggest that manganese oxidation in the water did not have a significant influence on the manganese fluxes measured at studied sites.

The correlation between manganese flux and concentration of manganese in porewater may be not observed if ferromanganese nodules, crusts and manganese oxides occur at the sediment surface. In this case dissolved manganese in the porewater may be adsorbed and trapped in the surface layer of sediment, and manganese flux may be much lower than a value predicted from its concentration gradient or may even be equal to zero (Canfield et al., 1993). Such a behavior of manganese was not observed for the sites studied in this work. In spite of the presence of ferromanganese nodules at stations Kasuuni (03)-(05), adsorption of dissolved manganese did not occur and manganese fluxes were still high. A possible explanation is that these nodules were decomposing, inert and/or had their adsorption sites saturated.

Chamber measured fluxes of total dissolved manganese were dominated by Mn(II). Dissolved manganese obtained by the formaldoxyme method may exist as Mn (II) and $\mathrm{Mn}$ (III). It is known that $\mathrm{Mn}$ (III) compounds exist only under suboxic conditions where $c\left(\mathrm{O}_{2}\right)<3 \mu \mathrm{M}$ 
and $c\left(\mathrm{H}_{2} \mathrm{~S}\right)<0.2 \mu \mathrm{M}$ (Trouwborst et al., 2006). In our study such conditions were clearly observed only at the station PV1(05) and changed very fast (during about $6 \mathrm{~h})$ to anoxic. Therefore, the presence of dissolved $\mathrm{Mn}$ (III) may be neglected, and we supposed that in this work dissolved manganese was present as dissolved Mn (II) only. Manganese complexed with organic matter was in most cases not involved in the exchange: its initial concentrations in the bottom water could be equal to practically zero or up to $4.5 \mu \mathrm{M}$ (in the Vistula Lagoon), and initial levels remained mostly constant during incubations. Fluxes of organically complexed manganese were observed only at stations 1.2001 and 1.2002 in the Vistula Lagoon and reached $20 \%$ of the total manganese fluxes.

The manganese fluxes obtained from the chamber incubations were in all cases higher than those calculated from the porewater gradients. The calculated fluxes represent diffusive fluxes while chamber incubations provide the total flux, which is the sum of the diffusive flux and the flux related to faunal activities such as bioirrigation and depend on processes occurring in the near-bottom water (e.g., Rutgers van der Loeff et al., 1984; Glud et al., 1994; Tengberg et al., 2004). In case when $J_{\mathrm{ch}} / J_{\mathrm{pw}}>1$, the biogenic transport, bioirrigation or reactions at the interface leading to an additional release of manganese become very important. When $J_{\mathrm{ch}} / J_{\mathrm{pw}}<1$, a large proportion of the upward diffusing manganese is oxidized or adsorbed. The first case was observed in the study of Warnken et al. (2001) where diffusion constituted $5-38 \%$ of the flux across the sediment-water interface. Thamdrup et al. (1994) found that calculated diffusive Mn fluxes towards the sediment surface were 3-16 times higher than the benthic effluxes, which demonstrated high rates of manganese oxidation in the thin oxic surface layer. In the study of Aller (1994) both cases were observed with the high variations: $0.5<J_{\mathrm{ch}} / J_{\mathrm{pw}}<3$ with a mean value of 0.9 .

In this study diffusive exchange of manganese constituted only $25-70 \%$ of the measured flux determined using chamber incubations. For the Golubaya Bay the diffusive manganese fluxes were on average 3.3 times lower than chamber measured fluxes (Fig. 3a). For the Vistula Lagoon and the GoF, the diffusive fluxes were 2.8 times lower than the fluxes measured in chambers (Fig. 3b, c). The highest chamber and diffusive fluxes were found at the same station (station $\operatorname{Kas}(05)$ in the GoF). Likewise the lowest chamber and diffusive fluxes were obtained at the same station (station 3 in the Golubaya Bay).

There was nevertheless a good correlation between chamber and diffusive fluxes which supports the sug- gestion that for the studied stations the manganese flux was mainly controlled by its concentration in the porewater of the top sediment layer and did not depend on redox conditions and processes in bottom water and at the top layer of sediment.

\subsection{Iron}

The chamber measured and diffusive fluxes of total iron differed much more than for manganese, $0.01<J_{\mathrm{ch}} /$ $J_{\mathrm{pw}}<50$ (Fig. 4). The anoxic/oxic boundary at the sediment-water interface was efficient in oxidizing and precipitating (or trapping) the iron. If the concentration of oxygen in the chambers did not drop below approximately $100 \mu \mathrm{M}$, practically no release of iron was observed, even if the porewater gradient predicted a high efflux. Chamber fluxes of iron in these cases did not exceed 10 (this study) - $17 \mu$ mole $\mathrm{m}^{-2}$ day $^{-1}$ (Warnken et al., 2001; Berelson et al., 2003). Processes such as bioirrigation, sediment resuspension and reactions at the interface appeared much more important for iron fluxes than for manganese fluxes. This resulted in much more intensive release of iron (up to an order of magnitude higher) from the sediment than it is possible due to diffusion only.
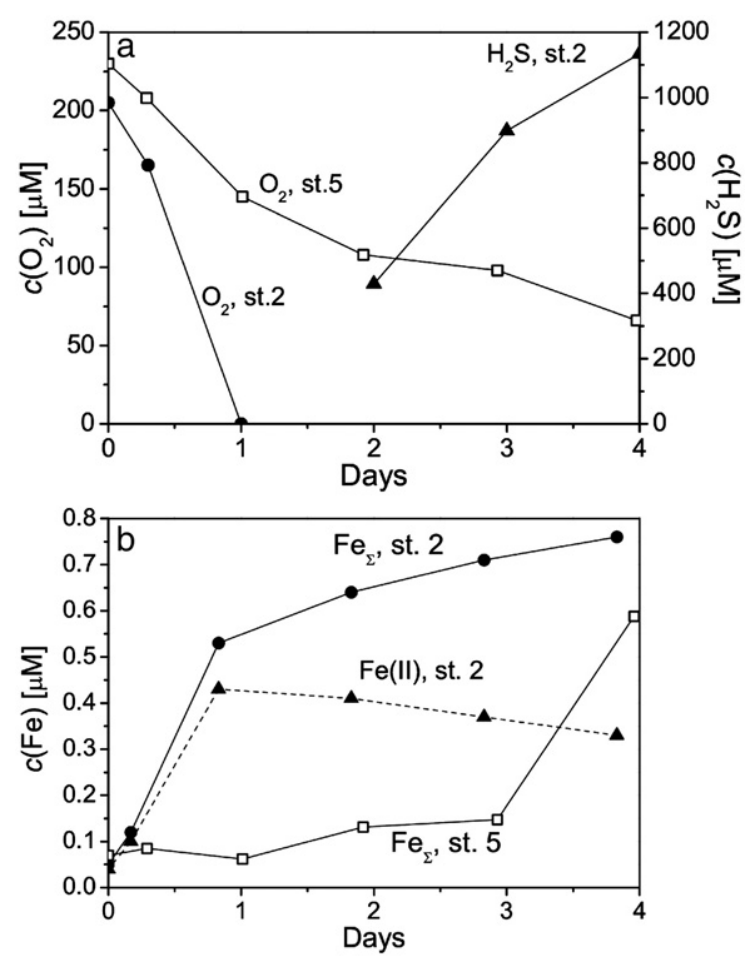

Fig. 7. The dynamics of concentrations of oxygen and hydrogen sulfide (a) and iron (b) inside incubation chambers on stations 2 and 5 , the Golubaya Bay (Black Sea). 
As expected the total iron fluxes were significantly influenced by the prevailing bottom water redox conditions. This can be illustrated by the measurements in the GoF (Fig. 4). At the oxic stations the concentration of iron in the chamber water was below the detection limit, and fluxes of iron could consequently not be detected. At the anoxic stations (GF1, GF2) iron fluxes were observed, but at rather low rates $\left(J_{\mathrm{ch}}=100\right.$ $200 \mu$ mole $\mathrm{m}^{-2}$ day $^{-1}$, Fig. 4). At the occasionally suboxic stations PV1(03) and PV1(05) the oxygen concentrations in the bottom water were around $0-10 \mu \mathrm{M}$ at a couple of deployments, and then high fluxes of iron were measured (1000 $\mu$ mole $\mathrm{m}^{-2}$ day $^{-1}$, Fig. 4).

The same tendency was observed for the stations in the Golubaya Bay. While the concentration of oxygen was high, there was no detectable flux of iron (Fig. 7, station 5, the first half of incubation). When concentration of oxygen had dropped below $100 \mu \mathrm{M}$ and before the appearance of hydrogen sulfide in the chamber, an intensive release of iron was triggered (Fig. 7). When hydrogen sulfide started to appear in the chamber water, the total iron flux decreased (Fig. 7, station 2, the second half of incubation). A positive linear relation was found between iron and oxygen fluxes for the stations in the Golubaya Bay (Fig. 5b).

In contrast to manganese, for which no regional particularities were detected, each region had its specific character for iron (Fig. 8). We hypothesize that in case of iron not only porewater was involved in the exchange processes, but also the solid phase of the top sediment layer. This was supported by results from the sediment resuspension experiments in the GoF (Almroth et al., personal communication), where on station PV1(03) concentration of iron in the chamber water sharply increased by the factor of 10 and exceeded the porewater

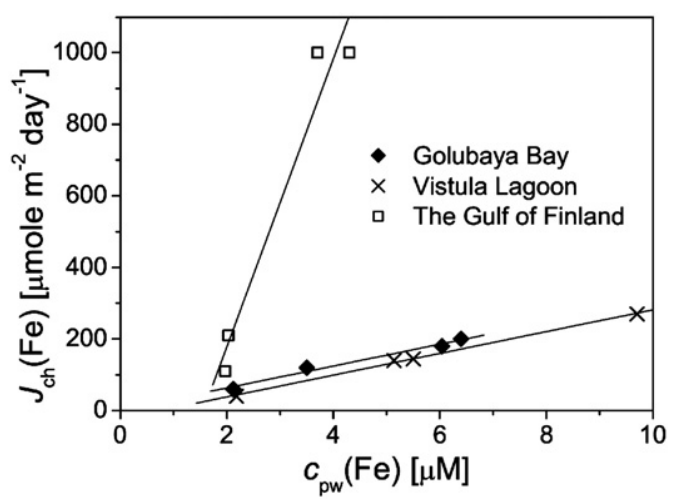

Fig. 8. Correlations of dissolved iron flux to concentration of dissolved iron in porewater of the top sediment layer $(0-1 \mathrm{~cm}) \cdot r^{2}=0.991$, $0.999,0.976(n=4, P=0.05)$ for the Golubaya Bay, the Vistula Lagoon and the Gulf of Finland, respectively. concentration twice as much right after the surface sediment layer was resuspended. It appeared that resuspended iron particles rapidly dissolved in the chamber water. These particles could not be iron oxyhydroxides because no oxygen was found in the bottom water. Another possible reason of such a sharp increase of iron concentration could be a release of dissolved iron compounds which were reversibly adsorbed at the surface of sediment. The reversible adsorption-desorption is a fast process and is possible not only in case of resuspension. At station PV1(05) an increase of iron concentration $\left(c_{\mathrm{ch}} / c_{\mathrm{pw}}\right.$ up to 5$)$ was observed without sediment resuspension. This could be a dissolution of iron oxyhydroxides from the surface layer of sediment when initially present oxygen was completely depleted and reducing conditions in bottom water were created or, again, a desorption of reversibly adsorbed compounds of iron. Analysis of iron species at this station showed that the flux of iron(III) constituted only $7 \%$ of the total iron flux. This means that either reduction of iron(III) oxides went very fast and resulted in the observed iron(II) flux or some iron(II) compounds were dissolved or desorbed during incubation as at the station PV1(03). Such a phenomenon was never observed for manganese, for which $c_{\mathrm{ch}}<c_{\mathrm{pw}}$ during all incubations. The content of iron in the sediment solid phase was similar, $0.9-1.8 \%$ and $1.1-1.7 \%$ of sediment dry weight for the Golubaya Bay and the Vistula Lagoon, respectively. In the GoF the iron levels were higher, generally about $4 \%$ of sediment solid phase. This difference explains probably the disagreement for iron fluxes in different regions (Fig. 8) and supports the supposition that the solid phase of the top sediment layer is involved in the exchange of the dissolved iron across the bottom water-sediment interface.

In case of the Golubaya Bay and the Vistula Lagoon the regression lines passed through origin of coordinates (Fig. 8), which, as well as in case of manganese, indicates that the absence of iron in the porewater will result in a zero flux. In case of the GoF, a zero flux of iron corresponds to an iron porewater concentration of $1.5 \mu \mathrm{M}$. At lower concentration the flux will be directed into sediment. A plausible explanation is that the sites in the GoF at which we detected iron fluxes were reduced, and bottom water was either anoxic or suboxic. This implies that when the concentration of iron exceeds some saturation level, iron sulfides start to precipitate inducing sediment uptake. Such situations are unlikely in the Vistula Lagoon and for the majority of stations in the Golubaya Bay, because both bottom water and top layers of sediment remained oxic. It should however be noted that for some stations rich in organic silt in the 
Golubaya Bay, conditions in the chamber water during incubations rapidly changed to anoxic which resulted in a flux of iron(II) directed into the sediment (Fig. 7, station 2), indicating precipitation of iron sulfide.

The proportion of iron(II) and iron(III) chamber measured fluxes reflected the proportion of dissolved iron(II) and iron(III) concentrations observed in porewater of the top sediment layer. Flux of iron(II) dominated for all studied stations. The contribution of iron(III) to the total dissolved iron flux did not exceed $20 \%$.

Data on fluxes of organically complexed iron obtained by the two methods (chamber experiment and porewater analysis) mostly did not agree. The behavior of organically complexed iron at the sediment-water interface was similar as for organically complexed manganese. The measured fluxes were in most cases low to insignificant. It has been reported that a large fraction of total iron in seawater can be represented by the organically complexed form (Lewis et al., 1995; Liu and Millero, 2002; Powell et al., 1995), which results in an increased concentration of dissolved iron in the sea water under oxic condition. An indication of this was noticed in the organic-rich waters of the Vistula Lagoon where dissolved iron(II) was present at concentrations of up to $0.2 \mu \mathrm{M}$ even in oxygen-rich bottom water, the concentration of organically complexed iron was up to $1.1 \mu \mathrm{M}$, and the flux of organically complexed iron reached up to $70 \%$ of the total iron flux on stations 1.2001 and 1.2002 . This also supports a supposition of strong bonding of iron by organic matter in contrast to manganese. Furthermore, at this site a release of iron(II) from the porewater was observed at oxygen levels that exceeded $100 \mu \mathrm{M}$. This was not the case for the Golubaya Bay and the GoF.

\section{Conclusions}

Benthic fluxes of manganese were found to correlate with manganese concentration in the porewater of the top sediment layer positively. The manganese fluxes were not influenced by redox conditions in the nearbottom water. On a large timescale manganese fluxes depend on redox conditions in bottom water, because a change of redox conditions would lead to a change of dissolved manganese content of the porewater. However, on a timescale of a single chamber incubation manganese fluxes did not depend on oxygen concentration (redox conditions), because for dissolved manganese the rate of oxidation is much lower than the rate of release from sediment. Diffusive flux of manganese constitutes $25-70 \%$ of the measured flux determined with the chamber incubation (on average $J_{\mathrm{ch}} / J_{\mathrm{pw}}=3$ ). This indicates that another process such as bacterial dissolution or bioirrigation also plays an important role in manganese benthic flux formation.

Our results showed the importance of bottom water redox conditions for benthic iron fluxes. We measured no fluxes at oxic conditions, intermediate fluxes at anoxic conditions and high fluxes at suboxic conditions. Oxidation of released dissolved iron occurred very rapidly under oxic conditions right after its release from the sediment. Under suboxic and anoxic conditions in the bottom water, the iron flux was dependent both on its concentration in porewater of the surface sediment and on the content of iron in the solid phase of sediment. The chamber measured and diffusive fluxes of total iron differed much more than for manganese, $0.01<J_{\mathrm{ch}} /$ $J_{\mathrm{pw}}<50$. Thus, bioirrigation, sediment resuspension and chemical processes at the interface are much more important for iron fluxes than for manganese fluxes.

The flux of iron was dominated by iron(II) under the studied conditions. Contribution of iron(III) to the total iron flux did not exceed $20 \%$. In the Vistula Lagoon metalorganic complexes contributed up to $20 \%$ of the total manganese flux and up to $70 \%$ of the total iron flux. Organically complexed manganese and iron at the other stations were mostly not involved in the benthic exchange.

\section{Acknowledgements}

We thank Elin Almroth and Henrik Andersson for their assistance during expeditions. Financial support was provided by the EU/INTAS project 2001-0735, the Russian Foundation for Basic Research, project 01-0564060a, the Swedish Research Council for Environment, Agriculture Sciences and Spatial Planning (FORMAS), and the Swedish Environmental Protection Agency (NV).

\section{References}

Aller, R.C., 1994. The sedimentary Mn cycle in Long Island Sound: its role as intermediate oxidant and the influence of bioturbation, $\mathrm{O}_{2}$, and $\mathrm{C}_{\text {org }}$ flux on diagenetic reaction balances. Journal of Marine Research 52, 259-295.

Bacon, M.P., Brewer, P.G., Spencer, D.W., Murray, J.W., Goddard, J.D., 1980. Lead-210, polonium-210, manganese and iron in the Cariaco Trench. Deep-Sea Research 27, 119-135.

Balzer, W., 1982. On the distribution of iron and manganese at the sediment/water interface: thermodynamic vs kinetic control. Geochimica et Cosmochimica Acta 46, 1153-1161.

Barnett, P.R.O., Watson, J., Connely, D., 1984. A multiple corer for taking virtually undisturbed samples from shelf, bathyal and abyssal sediments. Oceanologica Acta 7, 399-408.

Berelson, W., McManus, J., Coale, K., Johnson, K., Burdige, D., Kilgore, T., Colodner, D., Chavez, F., Kudela, R., Boucher, J., 2003. A time series of benthic flux measurements from Monterey Bay, CA. Continental Shelf Research 23, 457-481. 
Berner, R.A., 1980. Early Diagenesis: A Theoretical Approach. Princeton Univ. Press.

Canfield, D.E., Thamdrup, B., Hansen, J.W., 1993. The anaerobic degradation of organic matter in Danish coastal sediments: iron reduction, manganese reduction and sulfate reduction. Geochimica et Cosmochimica Acta 57, 3867-3883.

Fones, G.R., Davison, W., Holby, O., Jorgensen, B.B., Thamdrup, B., 2001. High-resolution metal gradients measured by in situ DGT/ DET deployment in Black Sea sediments using an autonomous benthic lander. Limnology and Oceanography 46, 982-988.

Friedl, G., Dinkel, C., Wehrli, B., 1998. Benthic fluxes of nutrients in the northwestern Black Sea. Marine Chemistry 62, 77-88.

Glud, R.N., Gundersen, J.K., Jørgensen, B.B., Revsbech, N.P., Schulz, H.D., 1994. Diffusive and total oxygen uptake of deep-sea sediments in the eastern South Atlantic Ocean: in situ and laboratory measurements. Deep-Sea Research 41, 1767-1788.

Grashoff, K., Kremling, K., Ehrhard, M., 1999. Methods of Seawater Analysis. 3rd completely revised and extended edition. Wiley$\mathrm{VCH}$, Weinheim.

Hallberg, R.O., Bagander, L.E., Engvall, A.E., Schippel, F.A., 1972. Method for studying geochemistry of sediment-water interface. Ambio 1, 71-72.

Jahnke, R.A., Christiansen, M.B., 1989. A free-vehicle benthic chamber instrument for sea floor studies. Deep-Sea Research 36, $625-637$.

Kononets, M.Yu., Pakhomova, S.V., Rozanov, A.G., Proskurnin, M.A., 2002. Determination of soluble iron species in seawater using ferrozine. Journal of Analytical Chemistry 57, 704-708.

Kremling, K., 1983. The behaviour of $\mathrm{Zn}, \mathrm{Cd}, \mathrm{Cu}, \mathrm{Ni}, \mathrm{Co}, \mathrm{Fe}$ and $\mathrm{Mn}$ in anoxic baltic water. Marine Chemistry 13, 87-108.

Landing, W.M., Westerlund, S., 1988. The solution chemistry of iron(II) in Frammenfjord. Marine Chemistry 23, 329-343.

Lewis, B.L., Landing, W.M., 1991. The biochemistry of manganese and iron in the Black Sea. Deep-Sea Research 38 (suppl. 2), S773-S803.

Lewis, B.L., Holt, P.D., Taylor, S.W., Wilhelm, S.W., Trick, C.G., Butler, A., Luther III, G.W., 1995. Voltammetric estimation of iron (III) thermodynamic stability constants for catecholate siderophores isolated from marine bacteria and cyanobacteria. Marine Chemistry $50,176-188$.

Li, J.-H., Gregory, S., 1974. Diffusion of ions in sea water and in deepsea sediments. Geochimica et Cosmochimica Acta 38, 703-714.

Lindstrom C.H.M., 1980. Transformation of iron constituents during early diagenesis. In-situ studies of a Baltic Sea sediment-water interface. Contributions in Microbial Geochemistry No. 4. Department of Geology, Stockholm University.

Liu, X., Millero, F.J., 2002. The solubility of iron in seawater. Marine Chemistry 77, 43-54.

Pakhomova, S.V., 2005. Rastvorennye formy zheleza i margantsa $\mathrm{v}$ vodnoi tolsche, osadkah i na granitse razdela voda-dno (Dissolved iron and manganese species in water column, sediments and at water-sediment interface). PhD theses, P.P. Shirshov Institute of Oceanology, Moscow. (in Russian).

Peshkova, V.M., Ovsyannikova, A.A., 1937. Kolorimetricheskoye opredeleine magantsa formaldoximom (colorimetric determination of manganese with formaldoxyme). Zavodskaya Laboratoriya 7 , 800-803. (in Russian).

Ponomarev, A.I., 1961. Metody khimicheskogo analiza silikatnyh i karbonatnyh gornyh porod (methods of chemical analysis of silicate and carbonate rocks). Izd. Akad. Nauk SSSR, Moscow. (in Russian).

Powell, R.T., King, D.W., Landing, W.M., 1995. Iron distributions in surface waters of south Atlantic. Marine Chemistry 50, 13-20.
Rutgers van der Loeff, M., Anderson, L., Hall, P., Iverfeldt, Å., Josefson, A., Sundby, B., Westerlund, S., 1984. The asphyxiation technique: an approach to distinguishing between molecular diffusion and biologically mediated transport at the sedimentwater interface. Limnology and Oceanography 29, 675-686.

Skoog, A., Hall, P.O.J., Hulth, S., Paxéus, N., Rutgers van der Loeff, M., Westerlund, S., 1996. Early diagenetic production and sediment-water exchange of fluorescent dissolved organic matter in the coastal environment. Geochimica et Cosmochimica Acta 60, 3619-3629.

Spencer, D.W., Brewer, P.G., 1971. Vertical advection diffusion and redox potential as controls on the distribution of manganese and other trace metals dissolved in water of the Black Sea. Journal of Geophysical Research 76, 5877-5892.

Spencer, D.W., Brewer, P.G., 1972. Aspect of the distribution and trace element composition of suspended matter in the Black Sea. Geochimica et Cosmochimica Acta 36, 71-86.

Ståhl, H., Tengberg, A., Brunnegård, J., Hall, P.O.J., 2004. Recycling and burial of organic carbon in sediments of the Porcupine Abyssal Plain, NE Atlantic. Deep-Sea Research 51, 777-791.

Sundby, B., Anderson, L.G., Hall, P.O.J., Iverfeldt, A., Rutgers van der Loeff, M., Westerlund, S., 1986. The effect of oxygen on release and uptake of cobalt, manganese, iron and phosphate at the sedimentwater interface. Geochimica et Cosmochimica Acta 50, 1281-1288.

Tebo, B.M., 1991. Manganese(II) oxidation in the suboxic zone of the Black Sea. Deep-Sea Research 38 (suppl. 2), S883-S905.

Tengberg, A., Almroth, E., Hall, P.O.J., 2003. Resuspension and its effect on organic carbon recycling and nutrient exchange in coastal sediments: in-situ measurements using new experimental technology. Journal of Experimental Marine Biology and Ecology 285-286, $119-142$.

Tengberg, A., Ståhl, H., Gust, G., Muller, V., Arning, U., Andersson, H., Hall, P.O.J., 2004. Intercalibration of benthic flux chambers: I. Accuracy of flux measurements and influence of chamber hydrodynamics. Progress in Oceanography 60, 1-28.

Tengberg, A., Hovdenes, J., Andersson, H.J., Brocandel, O., Diaz, R., Hebert, D., Arnerich, T., Huber, C., Körtzinger, A., Khripounoff, A., Rey, F., Rönning, C., Schimanski, J., Sommer, S., Stangelmayer, A., 2006. Evaluation of a lifetime-based optode to measure oxygen in aquatic systems. Limnology and Oceanography: Methods 4, 7-17.

Thamdrup, B., Glud, R.N., Hansen, J.W., 1994. Manganese oxidation and in situ manganese fluxes from a coastal sediment. Geochimica et Cosmochimica Acta 58, 2563-2570.

Trouwborst, R.E., Clement, B.G., Tebo, B.M., Glazer, B.T., Luther III, G.W., 2006. Soluble Mn(III) in suboxic zones. Science 313, $1955-1957$.

Vershinin, A.V., Rozanov, A.G., 1999. Results of the studies on chemical exchange through the bottom-water interface. Oceanology $39,772-783$.

Vershinin, A.V., Rozanov, A.G., 2002. Khimicheskiy obmen na granitse voda-dno v okeanakh i moryah (Chemical Exchange at the Water-sediments Interface in the Oceans and Seas). Geos, Moscow. (in Russian).

Warnken, K.W., Gill, G.A., Griffin, L.L., Santschi, P.H., 2001. Sediment-water exchange of $\mathrm{Mn}, \mathrm{Fe}, \mathrm{Ni}$ and $\mathrm{Zn}$ in Galveston Bay, Texas. Marine Chemistry 73, 215-231.

Yudin, M.V., Ezhova, E.E., Polunina, Yu.Yu., Vershinin, A.V., Rozanov, A.G., 2005. Investigation of dissolved oxygen fluxes across the water-sediment interface in the Vistula Lagoon of the Baltic Sea. Oceanology 45, 360-365.

Zhang, J.-Z., Millero, F.J., 1993. The chemistry of the anoxic waters in the Cariaco Trench. Deep-Sea Research 40, 1023-1041. 